\title{
Article
}

\section{Evaluating Business Model for Hotel Industry by Grey-TOPSIS}

\author{
Hsueh-Feng Chang ${ }^{1}$, Shu-Hua Wu ${ }^{2}$ D, Joyce Hsiu-Yu Chen ${ }^{2, *}$ and Chao-Hui Ke ${ }^{3}$ \\ 1 Department of Tourism Management, National Kaohsiung University of Science and Technology, \\ Kaohsiung 824004, Taiwan; anniechang@nkust.edu.tw \\ 2 Department of Food \& Beverage Management, National Kaohsiung University of Hospitality and Tourism, \\ Kaohsiung 812018, Taiwan; sue@mail.nkuht.edu.tw \\ 3 Department of Tourism, Chienkuo Technology University, Chunghua 500020, Taiwan; km870612@gmail.com \\ * Correspondence: joyce@staff.nkuht.edu.tw
}

Citation: Chang, Hsueh-Feng,

Shu-Hua Wu, Joyce Hsiu-Yu Chen, and Chao-Hui Ke. 2021. Evaluating Business Model for Hotel Industry by Grey-TOPSIS. Journal of Risk and Financial Management 14: 606. https://doi.org/10.3390/jrfm14120606

Academic Editor: Shigeyuki Hamori

Received: 14 October 2021

Accepted: 7 December 2021

Published: 15 December 2021

Publisher's Note: MDPI stays neutral with regard to jurisdictional claims in published maps and institutional affiliations.

Copyright: (c) 2021 by the authors. Licensee MDPI, Basel, Switzerland. This article is an open access article distributed under the terms and conditions of the Creative Commons Attribution (CC BY) license (https:// creativecommons.org/licenses/by/ $4.0 /)$.

\begin{abstract}
Businesses in the past few years have paid more and more attention to brand awareness. More and more branded hotels have launched sub-brands so as to access a new market, boost brand exposure and value, and attain new market niches. The purpose of the work was to explore, on the basis of the business model, factors affecting hotel sub-brand development in Taiwan. The modified Delphi method was firstly referred to. Next, a questionnaire was designed to serve as the basis of quantitative analysis. Third, experienced professionals from the hotel business were invited to participate in a questionnaire survey. The affecting factors of hotel sub-brand development were identified, and analysis data were generated. Grey-TOPSIS was employed to evaluate, calculate, and certify weight analysis and ranking of affecting indices of hotel sub-branding. The results explained that there are nine affecting factors for developing a hotel's sub-branding. They are channel, target customers, customer relationship, key activities, revenue model, key partners, value proposition, key resources, and cost structure. The top four are the most important ones. This finding, figured out by using soft mathematical methods, can provide a proper evaluating way for decision making by the hotel industry, which wants to establish its sub-brands.
\end{abstract}

Keywords: business model; hotel industry; sub-brand; modified Delphi method; Grey-TOPSIS

\section{Introduction}

Businesses have constantly changed their management types. Currently, they are placing more and more stress on brand value along with product quality and function (Chen et al. 2015). A brand refers to a name, a noun, a mark, or a design (Kotler et al. 1996). A brand is a unique name or symbol that distinguishes its product or service from that of a business rival (Aaker 1991). Additionally, the relationships between brands influence brand identity and reputation (Barros et al. 2020). Future marketing is bound to be a brand war. The only way to possess a market is to possess a brand with market advantage (Light and Kiddon 2009). To attain growth, a business needs either to go overseas or to extend its brand (Koh 2012). Brand extension, or brand stretching, is a marketing strategy whereby a firm that markets a product with a well-developed image uses the same brand name for an improved product, a new product line, or the same product in a new form. In brand extension, a business applies the parent brand name to different kinds of products (Kotler 1991). In product line extension, a business applies the original brand to the same product in a new form (Tauber 1981). Brand management has shifted from the tactical level in the past to a strategic level for enhancing value. How companies can use powerful tools to examine their brands has become an issue that cannot be ignored.

So far, more and more businesses have possessed one or more than one sub-brands in addition to a main brand. Brand expansion and sub-brand extension are meant to attract consumers. It has been trendy for Taiwanese tour hotels to develop sub-branding. These sub-brands focus mainly on providing lodging. Sub-branding involves renovating aged 
hotels, building hotel self-specialty, offering medium prices, and attracting young people. Silks Hotel Group, for example, has promoted "just sleep"; W Hotel, Aloft; and Evergreen International Hotels, Evergreen Palace Hotels-Chiayi. They all aim to provide consumers with knowledge about organizational products and services through their brands, thus enticing consumers to purchase their products (Magretta 2002). Hotels can, therefore, obtain their value. Therefore, enterprises must continuously innovate to maintain their competitive advantages, and innovation ability is the key factor for the success of enterprises (Taques et al. 2020). Geissdoerfer et al. (2017) advocated that the process of business model construction and modification is the business model innovation and forms a part of business strategy. Recently, chain-branded hotels in Taiwan have poured a lot of resources into development of their sub-brands, so as to attract different consumer groups and satisfy accommodation needs of different customers. How, among so many competitors, hotels can establish sub-brands to attract more customers is worth investigation.

A business model is a framework involving product, service, and information flow (Timmers 1998). It is also regarded as a principle, whereby a business creates, transmits, and obtains value (Osterwalder and Pigneur 2010). It needs to take into consideration cost reasonableness and attainment of value and benefit (Gambardella and McGahan 2010). As far as a business is concerned, innovation of a business model can not only assist it in firmly controlling market needs and transmitting value and obtaining profit but helps change the model of the industry (Chesbrough and Rosenbloom 2002; Teece 2010). Lüdeke-Freund et al. (2019) proposed that business model innovation is a means to alter and extend firms' abilities to act effectively and efficiently, as with any type of innovation. The issues of the competitive status formation of the hotel in changing economic conditions, growing instability of the environment, and constant transformation processes, which dictate the new rules for the market participants, require increased attention from scientists (Holliday et al. 2020). With this innovative business model, the hotel industry can decide influential factors and decision-making processes while establishing sub-brands. Based on Osterwalder's nine factors of a business model, namely, target customers, value proposition, market channel, customer relationship, key resources, key activities, key partners, cost structure, and revenue model, the paper investigates the strategy of hotel sub-branding. Research in the past has dealt with sub-branding in general. However, there has been little study concerned about hotel sub-brand development. There is, therefore, a shortage of literature in relation to hotel sub-brand development. The paper aims to investigate, on the basis of a business model, hotel sub-brand development.

Literature reveals that evaluation of key important factors involves various indices, meaning "multi-layer assessment." Some research has employed relatively subjective method. Grey system theory aims to analyze and investigate systems with uncertainty and insufficient information. It tries to effectively analyze and explore relationships between variables. TOPSIS (1) has a compensatory method that can produce the representative score of the best and the worst results, (2) sorts all results (good vs. bad) with objective judgment, and (3) selects the finest alternative for decision. The paper conducted two stages of analysis, including applying the modified Delphi method to establish the affecting factors of hotel sub-branding and employing Grey TOPSIS to evaluate weight analysis and ranking of factors affecting sub-branding development. The purpose of this research, therefore, was twofold. First, it identified the factors affecting hotel sub-brand development. Second, it analyzed the weight-affecting factors and sorted them in order of weight.

\section{Literature Review}

\subsection{Brand Extension and Sub-Brands}

In Taiwan, brand extension has become popular among hotels. Hotel brand expansion and of sub-brand extension are channels that transfer product value and social value to another industry (Hubbard and Armstrong 1994). Tauber mentioned that brand extension could readily enter a new product market based on consumer cognition of the parent brand, impression, and evaluation (Tauber 1981). In their study of brand extension in 
fashion products, Huang and Pan (2012) found there was a relationship between a parent brand and its sub-brand. A parent brand in combination with a sub-brand can reduce risk and cost of marketing a new product. Furthermore, the image of a parent brand can also increase consumer identity. A new sub-brand, consequently, can enter a new market with ease. Consumers are willing to accept the new product. Taiwan's hotels are no exception. They have, over the past few years, established sub-brands, which are regarded as an important niche market for expanding customer bases and brand development.

Brand extension links the positive image of a parent brand with a new product extended from the original one (Smith 1992). Tauber (1981) proposed a brand extension matrix. A growth matrix is developed on the basis of a business perspective. Two constructs, including brand name and product category, form a matrix. The classification of brand strategies clearly distinguishes product line extension from brand extension.

The four brand strategies are, respectively:

1. New product: A company uses a new brand to introduce, within an existing market category, a new product that is not similar to the product category the company already offers.

2. Flanker brand: A company introduces a new product by using a new brand name within an existing market category.

3. Franchise extension: This is achieved by offering more products (of a different nature/category) under the existing brand name that customers are familiar with.

4. Line extension: A product line extension introduces a new product, within an existing market, with different specifications and flavors, or a similar product.

Literature in the past demonstrated that quite a lot of businesses extended their brands by taking advantage of their parent brand, thus stabilizing market share of their parent brand and expanding a new market. Whether extension of a sub-brand can succeed depends on consumers' evaluations of the parent brand. There has been a lot of research dealing with brand extension. This kind of research seldom appeared in hotel brand extension. Most of the research focused on the brand equity, brand image, brand extension, and the relationship with sustainable development and competitive advantage (Hussain et al. 2020; Barros et al. 2020; Salguero et al. 2019). Tauber's flanker brand is regarded in the paper as a strategy of brand extension that would be a good example.

\subsection{Hotel's Sub-Branding in Taiwan}

The 21st century can be regarded as a brand-led era. As far as most hotels are concerned, they have already plunged into an era of "brand competition" (Chien and Hung 2018). International tour hotels have regarded brand value accentuation as their organizational goal (Tsen and Hu 2010). Recently, Taiwan's hotels have poured a huge amount of capital into brand promotion. They look forward to retaining consumers through sub-branding. Hotel groups including Silks Hotel Group, LDC Hotels \& Resorts, LeoFoo, Ambassador, Gloria, and My Humble House all aim to create more business opportunities by applying a "focus market".

According to Koh (2012), a sub-brand can reach out to customers to whom the parent brand may not be able to reach out. In order to attract different consumer groups, businesses may take advantage of the existing brand through upward or downward extension to attract new purchasers. Silks Hotel Group, for example, introduced Just Sleep as its subbrand. Hotel Royal Group introduced the Place Tainan and the Place Taichung as its sub brands. Le Meridien Taipei has Humble House Taipei as its sub brand. Ambassador Hotel \& Restaurants established Amba, which focuses mainly on environmental conservation, sci-tech, and innovation. Amba is quite different from the traditional Ambassador Hotel, which is gentlemen oriented. W Hotel introduced Aloft, which is price friendly and appeals mainly to business tourists and self-guided tourists. It is different from a five-star hotel. In the paper, a sub-brand is defined as an introduction of a new product under the parent brand within the existing product category. It should not violate the core concept 
and spirit of the original brand. It is established for a different orientation and different consumer groups.

\subsection{Business Model}

Innovation is redesigning or improving the products, services, and methods for an organization to survive (Zahra 1996; Tidd et al. 1997). To avoid the unmatching of products and services with market demands, enterprises need to develop new products and services (Eberhard and Craig 2013; Jansen et al. 2005). Without innovation, a business is very likely to become aged and eventually driven out of the market (Koh 2012). Process innovations increase profits for the organization through improved efficiencies and reducing costs (Johne and Davies 2000). Faced with a competitive environment, a business needs to constantly renew itself, which is a key to sustainable management (Guarascio and Tamagni 2019).

The business model aims to create more value for consumers (Magretta 2002). Renovation of a business model changes the type of industry and redistributes industrial value (Amit and Zott 2001; Cavalcante et al. 2011; Chesbrough 2010; Teece 2010). The business model needs to consider the rationality of cost and the acquisition of value benefits (Gambardella and McGahan 2010). Based on the previous research, whatever the concept of business model innovation, there is a general consensus that business model innovation often affects the whole enterprise (Amit and Zott 2001; Zhang et al. 2018).

Hospitality products are difficult to protect through patents and copyrights. Therefore, continuous innovation of products by applying customer value creation (Sharmelly and Klarin 2021) is needed for hospitality firms to stay ahead of competitors (Agarwal et al. 2003). Maintaining and establishing competitive advantages for hotels within a fastchanging environment to meet market demands and more attention from enterprises is necessary. It is not easy for hotels to develop a new business model. The key to boosting business advantages depends on how to make use of market needs and possess key technology (Benner and Tushman 2002). However, there are many requirements to meet before developing a sub-brand in hotels. Past research cannot effectively explain how the hotel industry can use core resources to achieve sustainable development with limited resources, which requires further in-depth discussion.

In "Business Model Generation", Osterwalder and Pigneur (2010) pointed out that a business model describes how an organization created and transmitted value to customers, whereby it obtained profit. A business model consists of nine indices, including target customers, value proposition, market channel, customer relationship, key resources, key activities, key partners, cost structure, and revenue model.

The nine indicators of the business model are as follows. (1) Target Customer Segments is the specific customer group to be targeted by the company (Chien and Hung 2018; Johne and Davies 2000; Agarwal et al. 2003). (2) Value Proposition is the unique value created by the company for its target customer segment to meet its needs (Sharmelly and Klarin 2021; Chen et al. 2015). (3) Channels are the ways or the paths that can be used to communicate and convey the value to the target customer (Kim et al. 2017; Ghahtarani et al. 2020; Tiago et al. 2021; Zhang et al. 2018). (4) Customer Relationships are the relationships established between the company and the specific target. There will be different types of relationships according to the level of the relationship (Ghahtarani et al. 2020). (5) Key Resources are the most important assets required for the business model, such as human resources or financial resources (Hussain et al. 2020; Dhiman and Arora 2020; Salguero et al. 2019). (6) Key activities are the most important must-dos required for the operation of a business model, such as problem solving, production, etc. (7) Key partners are the most important supplier and partner for the operation of the business model (Kim et al. 2017; Tiago et al. 2021). (8) Cost structure refers to all costs incurred in operating a business model. (9) Revenue Streams is the money that the company generates from each customer segment. Based on this business model, developed by Osterwalder and Pigneur (2010), and the related reference, this study proposed the main factors affecting the development of the hotel's sub-brand. 


\subsection{Evaluation and Factor Selection}

The paper employed the business model proposed by Osterwalder and Pigneur. By referring to literature and conducting expert interviews, the researcher designed the preliminary framework of a business model of hotel sub-branding. Table 1 indicates the nine dimensions and evaluation factors.

Table 1. The dimensions and evaluation factors.

\begin{tabular}{|c|c|}
\hline Dimension & Factor \\
\hline Value proposition & Customer value, market segmentation, and service quality \\
\hline Target customers & $\begin{array}{l}\text { Specified target customers (business), market share (market estimate), } \\
\text { and market segmentation }\end{array}$ \\
\hline Marketing channel & $\begin{array}{c}\text { Online booking system (sci-tech channel), travel agent, logistics, ads } \\
\text { and promotion, web platform management and marketing, promotion } \\
\text { and special project success rate }\end{array}$ \\
\hline Customer relationship & $\begin{array}{l}\text { Customer favor, customer satisfaction, customer retention rate } \\
\text { (customer repeat purchase rate), and customer loyalty }\end{array}$ \\
\hline Key resources & $\begin{array}{l}\text { Business image, hotel size, machine, land and plant, human resources } \\
\text { (training, personnel management, personnel allocation), financial } \\
\text { resources, resource input, patent, professional skills, production cost, } \\
\text { management system, overall image (brand, logo), cash, and resource } \\
\text { development (marketing, contract customer) }\end{array}$ \\
\hline Key activities & $\begin{array}{l}\text { Problem solution (traffic), post-sales service, production, internal flow, } \\
\text { operation flow, and staff production capacity }\end{array}$ \\
\hline Key partners & Supplier, strategic alliance, and collaborative partnership network \\
\hline Cost structure & $\begin{array}{l}\text { Fixed cost (product pricing), economies of scope (product cost of a single } \\
\text { company is lower than that of a professional company), value orientation } \\
\text { (seek to maintain the most money-saving cost structure), reducing cost of } \\
\text { revenue and production cost, increasing production capacity }\end{array}$ \\
\hline Revenue model & Growth of revenue, operating performance, and expenses for use \\
\hline
\end{tabular}

Based on the above literature reviews, this study believes that the development of sub-brands in hotels is an important innovative business model. However, in the past literature, there is no discussion on the affecting factors of hotel development sub-brands. What are these factors? Whether these affecting factors are consistent in importance is also worthy of analysis.

\section{Methodology}

The paper aimed to investigate affecting factors of hotel sub-brand development. Expert review of survey questionnaire was employed for empirical research. Expert selection was divided into two stages. The modified Delphi method, which investigated affecting factors of hotel sub-branding, was applied for the first stage. Seven experts from the hotel industry were invited to fill in the survey questionnaire. The second stage, to which Grey-OPSIS was applied, analyzed and sorted the weight or affecting factors.

\subsection{Modified Delphi Method}

Delphi technique, which aims to increase the quality of decision, establishes agreedupon opinions or reaches a consensus on the basis of expert specialties and experiences. It is meant for assessing and programming future decision. Employing Delphi technique can be time and energy consuming. A questionnaire needs to be delivered and returned repeatedly and questionnaire return rates can be low. In view of this inadequacy, this research applied a modified method. Instead of collecting expert opinions for open-ended questions, the work organized preliminary opinions by referring to reviewed literature and onsite expert interviews (Murry and Hammons 1995). The selected items had their origin 
either in related literature or expert interview. The modified Delphi method is similar to Delphi technique as to application and procedure. Thus, the modified Delphi method was applied for this research.

First, seven supervisors from hotels with sub-brands were invited to participate in the Delphi questionnaire survey. Two surveys were respectively conducted in December 2018 and in January-March 2019. The experts were asked to rate their agreement. The 5-point Likert scale, ranging from 5 points (strongly agree), through 4 points (agree), 3 points (neither agree nor disagree), 2 points (disagree), and to 1 point (strongly disagree), was employed. The mean and standard deviation of each item were generated. Kuo's 5-point equal interval division was adopted for agreement analysis. Expert agreement was divided into three levels including high-score group (3.667-5.000), mid-score group (2.334-3.666), and low-score group (1.000-2.333). A higher score means higher value (Kuo 2015).

The equation of quartile $Q$ is $0.5\left(Q_{3}-Q_{1}\right)$, wherein $Q 3$ is the answer from $75 \%$ empirical quartile, whereas Q1 is the answer from $25 \%$ empirical quartile. This equation can remove outliers by showing the collective answers given by $75 \%$, thus indicating a consensus degree (Holden and Wedman 1993). According to Faherty, an item with quartile $\leqq 0.60$ is regarded as having a certain degree of consensus, while a quartile falling between 0.60 and 1 is regarded as having moderate consensus (Faherty 1979).

\subsection{Grey-TOPSIS Method}

Yoon and Hwang (1995) proposed a technique for order preference by similarity to ideal solution (TOPSIS), a multi-criteria, decision-making method. The main feature is that, in the selection process of the decision-making plan to solve the problem, the positive ideal solution and the negative ideal solution are included at the same time. The ranking of the schemes obtained by this method can avoid generating schemes that are closest to the positive ideal solution and, at the same time, the closest to the negative ideal solution, the farthest from the positive ideal solution, and the farthest from the negative ideal solution, which is not easy to compare (Wen and Wen 2021).

Because the TOPSIS method is a frequently used, multi-objective, decision-making method, it is currently widely used in various research fields, such as regional economic development and internet public opinion. However, it can only respond to the relative position relationship of the data curve and cannot respond to the dynamic changes of the system. The grey entropy analysis method is a statistical analysis method that uses grey weighting to indicate the strength, size, and order of the relationship among elements. The influence factors for the establishment of sub-brands in hotels are a system of development and change, and the development trend must be quantitatively compared and analyzed. Therefore, the work referred to this feature and combined the TOPSIS method with the grey entropy method to make up for the defects of TOPSIS itself: It can be more systematic and effective. It accurately reflects the closeness between the alternative plan and the ideal plan and makes a more comprehensive evaluation for the hotel's sub-brand construction.

The calculation steps are listed below.

1. Given the analysis raw data,

$$
D=\begin{gathered}
A_{1} \\
A_{2} \\
A_{3} \\
\vdots \\
A_{m}
\end{gathered}\left[\begin{array}{ccccc}
x_{11} & x_{12} & x_{13} & \cdots & x_{1 n} \\
x_{21} & x_{22} & x_{23} & \cdots & x_{2 n} \\
x_{31} & x_{32} & x_{33} & \cdots & x_{3 n} \\
\vdots & \vdots & \vdots & \ddots & \vdots \\
x_{m 1} & x_{m 2} & x_{m 3} & \cdots & x_{m n}
\end{array}\right]
$$

2. Based on Equation (2), to normalize the original raw data, and shown in Equation (3),

$$
r_{i j}=\frac{x_{i j}}{\sqrt{\sum_{i=1}^{m} x_{i j}^{2}}}
$$




$$
R=\left[\begin{array}{ccccc}
r_{11} & r_{12} & r_{13} & \cdots & r_{1 n} \\
r_{21} & r_{22} & r_{23} & \cdots & r_{2 n} \\
r_{31} & r_{32} & r_{33} & \cdots & r_{3 n} \\
\vdots & \vdots & \vdots & \ddots & \vdots \\
r_{m 1} & r_{m 2} & r_{m 3} & \cdots & r_{m n}
\end{array}\right]
$$

3. Use grey entropy to obtain the objective weighting:

$$
e_{k}=\frac{1}{0.6478 \times m} \sum_{i=1}^{m} W_{e}\left(\frac{x_{i}(k)}{D_{k}}\right)
$$

where:

(1) $\quad x_{i}=\left(x_{i}(1), x_{i}(2), x_{i}(3), \ldots \ldots, x_{i}(k)\right), i=1,2,3, \ldots, m, k=1,2,3, \ldots, n$ are analysis raw sequences.

(2) $\quad D_{k}=\sum_{i=1}^{m} x_{k}(i)$ : The summation of each attribute

(3) $\quad m=\frac{1}{0.6478 \times k}$ : Normalization coefficient.

4. Calculate the normalization matrix by times weighting:

$$
V=\left[\begin{array}{ccccc}
\omega_{1} r_{11} & \omega_{2} r_{12} & \omega_{3} r_{13} & \cdots & \omega_{n} r_{1 n} \\
\omega_{1} r_{21} & \omega_{2} r_{22} & \omega_{3} r_{23} & \cdots & \omega_{n} r_{2 n} \\
\omega_{1} r_{31} & \omega_{2} r_{32} & \omega_{3} r_{33} & \cdots & \omega_{n} r_{3 n} \\
\vdots & \vdots & \vdots & \ddots & \vdots \\
\omega_{1} r_{m 1} & \omega_{2} r_{m 2} & \omega_{3} r_{m 3} & \cdots & \omega_{n} r_{m n}
\end{array}\right]=\left[\begin{array}{ccccc}
v_{11} & v_{12} & v_{13} & \cdots & v_{1 n} \\
v_{21} & v_{22} & v_{23} & \cdots & v_{2 n} \\
v_{31} & v_{32} & v_{33} & \cdots & v_{3 n} \\
\vdots & \vdots & \vdots & \ddots & \vdots \\
v_{m 1} & v_{m 2} & v_{m 3} & \cdots & v_{m n}
\end{array}\right]
$$

5. Find the positive ideal solution $A^{+}$and negative ideal solution $A^{-}$

$$
A^{+}=\max \cdot\left\{v_{i}^{+}\right\}=\left(v_{1}^{+}, v_{2}^{+}, v_{3}^{+}, \cdots, v_{m}^{+}\right), A^{-}=\min .\left\{v_{i}^{-}\right\}=\left(v_{1}^{-}, v_{2}^{-}, v_{3}^{-}, \cdots, v_{m}^{-}\right)
$$

6. Calculate the distance of positive ideal solution and negative ideal solution:

$$
S_{i}^{+}=\sqrt{\sum_{j=1}^{n}\left(v_{i j}-v_{j}^{+}\right)^{2}}, S_{i}^{-}=\sqrt{\sum_{j=1}^{n}\left(v_{i j}-v_{j}^{-}\right)^{2}}, i=1,2,3, \cdots, m
$$

7. Calculate the approaching degree ideal solution of each factor:

$$
C_{j}=\frac{S_{i}^{-}}{S_{i}^{+}+S_{i}^{-}}, i=1,2,3, \cdots, n, j=1,2,3, \cdots, n
$$

\section{Results and Discussion}

\subsection{Modified Delphi Method Analysis}

Based on a literature review and expert interviews, the preliminary framework of hotel sub-branding was generated. The modified Delphi method-based questionnaire survey was conducted on experts for their opinions. Table 2 shows the results of data analysis.

The construct analysis (first stage: the modified Delphi method) revealed that the nine factors affecting hotel sub-branding averaged 4.14 (on 5-point scale), suggesting a high degree of importance. According to the data analysis (second stage), the smaller the S.D. is, the more consistent experts' opinions are. The largest S.D. for the first stage was 1.07, and 0.76 for the second stage, indicating a decreased S.D. Quadratic analysis aims to understand the distribution of expert opinions. The smaller the quadratic interval is, the more consistent expert opinions are. Post second stage showed high degree of similarity. The $Q$ values of all items were $\leqq 0.60$. The highest $Q$ value for the first stage was 0.75 , and 0.5 for the second stage. This suggests a high degree of consensus among experts. 
Table 2. The results of data analysis by the Delphi method.

\begin{tabular}{|c|c|c|c|c|c|c|c|c|}
\hline \multirow{2}{*}{ Dimension } & \multicolumn{3}{|c|}{ 1st } & \multirow{2}{*}{ Mo } & \multicolumn{3}{|c|}{ 2nd } & \multirow{2}{*}{ Mo } \\
\hline & $M$ & S.D. & $Q$ & & $M$ & S.D. & $Q$ & \\
\hline Value proposition $\left(\mathrm{A}_{1}\right)$ & 4.43 & 0.53 & 0.50 & 4 & 4.58 & 0.54 & 0.50 & 5 \\
\hline Target customers $\left(\mathrm{A}_{2}\right)$ & 4.43 & 0.79 & 0.50 & 5 & 4.71 & 0.49 & 0.25 & 5 \\
\hline Marketing channel $\left(\mathrm{A}_{3}\right)$ & 4.43 & 0.53 & 0.50 & 4 & 5.00 & 0.00 & 0.00 & 5 \\
\hline Customer relationship $\left(\mathrm{A}_{4}\right)$ & 4.14 & 1.07 & 0.50 & 4 & 4.71 & 0.49 & 0.25 & 5 \\
\hline Key resources $\left(\mathrm{A}_{5}\right)$ & 4.00 & 0.82 & 0.50 & 4 & 4.57 & 0.54 & 0.50 & 5 \\
\hline Key activities $\left(\mathrm{A}_{6}\right)$ & 4.29 & 0.76 & 0.50 & 5 & 4.71 & 0.49 & 0.25 & 5 \\
\hline Key partners $\left(\mathrm{A}_{7}\right)$ & 4.14 & 0.90 & 0.75 & 5 & 4.14 & 0.69 & 0.25 & 4 \\
\hline Cost structure $\left(\mathrm{A}_{8}\right)$ & 4.29 & 0.49 & 0.25 & 4 & 4.57 & 0.54 & 0.50 & 5 \\
\hline Revenue model ( $\left.\mathrm{A}_{9}\right)$ & 4.29 & 0.76 & 0.50 & 4 & 4.29 & 0.76 & 0.50 & 4 \\
\hline
\end{tabular}

The work obtained experts' consensus and agreed-upon opinions by applying the modified Delphi method. The nine affecting factors, in order of importance, were channel (5.00), target customers (4.71), customer relationship (4.71), key activities (4.71), value proposition (4.58), key resources (4.57), cost structure (4.57), revenue model (4.29), and key partners (4.14).

\subsection{Grey-TOPSIS Analysis}

After completing the expert opinions and obtaining the nine influence factors, the Grey-TOPSIS calculation process was used for evaluation. The analysis steps were as follows. The meaning of $A_{1}$ to $A_{9}$ in all tables are: $A_{1}$ : Value proposition, $A_{2}$ : Target customers, $\mathrm{A}_{3}$ : Marketing channel, $\mathrm{A}_{4}$ : Customer relationship, $\mathrm{A}_{5}$ : Key resources, $\mathrm{A}_{6}$ : Key activities, $A_{7}$ : Key partners, $A_{8}$ : Cost structure, and $A_{9}$ : Revenue model.

1. The evaluation scores of each factor are shown in Table 3.

Table 3. The raw data of factors.

\begin{tabular}{ccccccccc}
\hline $\mathbf{A}_{\mathbf{1}}$ & $\mathbf{A}_{\mathbf{2}}$ & $\mathbf{A}_{\mathbf{3}}$ & $\mathbf{A}_{\mathbf{4}}$ & $\mathbf{A}_{\mathbf{5}}$ & $\mathbf{A}_{\mathbf{6}}$ & $\mathbf{A}_{\mathbf{7}}$ & $\mathbf{A}_{\mathbf{8}}$ & $\mathbf{A}_{\mathbf{9}}$ \\
\hline 5 & 5 & 5 & 5 & 5 & 4 & 4 & 5 & 4 \\
\hline 5 & 5 & 5 & 5 & 5 & 5 & 5 & 5 & 5 \\
\hline 5 & 5 & 4 & 5 & 5 & 5 & 4 & 4 & 4 \\
\hline 4 & 4 & 5 & 5 & 4 & 4 & 3 & 5 & 3 \\
\hline 5 & 5 & 3 & 5 & 5 & 5 & 5 & 5 & 5 \\
\hline 4 & 4 & 5 & 4 & 4 & 5 & 4 & 4 & 4 \\
\hline 4 & 5 & 5 & 4 & 4 & 5 & 4 & 4 & 5 \\
\hline
\end{tabular}

2. Use Equation (2) to obtain the normalization of original raw data, as shown in Table 4. And the weighting of each factor from grey entropy method are shown in Table 5.

Table 4. The normalization of original raw data.

\begin{tabular}{ccccccccc}
\hline $\mathbf{A}_{\mathbf{1}}$ & $\mathbf{A}_{\mathbf{2}}$ & $\mathbf{A}_{\mathbf{3}}$ & $\mathbf{A}_{\mathbf{4}}$ & $\mathbf{A}_{\mathbf{5}}$ & $\mathbf{A}_{\mathbf{6}}$ & $\mathbf{A}_{\mathbf{7}}$ & $\mathbf{A}_{\mathbf{8}}$ & $\mathbf{A}_{\mathbf{9}}$ \\
\hline 0.0338 & 0.0318 & 0.0333 & 0.0318 & 0.0338 & 0.0255 & 0.0325 & 0.0338 & 0.0303 \\
\hline 0.0338 & 0.0318 & 0.0333 & 0.0318 & 0.0338 & 0.0318 & 0.0407 & 0.0338 & 0.0379 \\
\hline 0.0338 & 0.0318 & 0.0267 & 0.0318 & 0.0338 & 0.0318 & 0.0325 & 0.027 & 0.0303 \\
\hline 0.027 & 0.0255 & 0.0333 & 0.0318 & 0.027 & 0.0255 & 0.0244 & 0.0338 & 0.0227 \\
\hline
\end{tabular}


Table 4. Cont.

\begin{tabular}{ccccccccc}
\hline $\mathbf{A}_{\mathbf{1}}$ & $\mathbf{A}_{\mathbf{2}}$ & $\mathbf{A}_{\mathbf{3}}$ & $\mathbf{A}_{\mathbf{4}}$ & $\mathbf{A}_{\mathbf{5}}$ & $\mathbf{A}_{\mathbf{6}}$ & $\mathbf{A}_{\mathbf{7}}$ & $\mathbf{A}_{\mathbf{8}}$ & $\mathbf{A}_{\mathbf{9}}$ \\
\hline 0.0338 & 0.0318 & 0.02 & 0.0318 & 0.0338 & 0.0318 & 0.0407 & 0.0338 & 0.0379 \\
\hline 0.027 & 0.0255 & 0.0333 & 0.0255 & 0.027 & 0.0318 & 0.0325 & 0.027 & 0.0303 \\
\hline 0.027 & 0.0318 & 0.0333 & 0.0255 & 0.027 & 0.0318 & 0.0325 & 0.027 & 0.0379 \\
\hline
\end{tabular}

Table 5. The weighting of each factor from the grey entropy method.

\begin{tabular}{ccccccccc}
\hline $\mathbf{A}_{\mathbf{1}}$ & $\mathbf{A}_{\mathbf{2}}$ & $\mathbf{A}_{\mathbf{3}}$ & $\mathbf{A}_{\mathbf{4}}$ & $\mathbf{A}_{\mathbf{5}}$ & $\mathbf{A}_{\mathbf{6}}$ & $\mathbf{A}_{\mathbf{7}}$ & $\mathbf{A}_{\mathbf{8}}$ & $\mathbf{A}_{\mathbf{9}}$ \\
\hline 0.1111 & 0.111 & 0.1112 & 0.111 & 0.1111 & 0.111 & 0.1112 & 0.1111 & 0.1113 \\
\hline
\end{tabular}

3. Use Equation (5) to obtain the decision matrix, as shown in Table 6.

Table 6. The decision matrix after adding weighting.

\begin{tabular}{ccccccccc}
\hline $\mathbf{A}_{\mathbf{1}}$ & $\mathbf{A}_{\mathbf{2}}$ & $\mathbf{A}_{\mathbf{3}}$ & $\mathbf{A}_{\mathbf{4}}$ & $\mathbf{A}_{\mathbf{5}}$ & $\mathbf{A}_{\mathbf{6}}$ & $\mathbf{A}_{\mathbf{7}}$ & $\mathbf{A}_{\mathbf{8}}$ & $\mathbf{A}_{\mathbf{9}}$ \\
\hline 0.0038 & 0.0035 & 0.0037 & 0.0035 & 0.0038 & 0.0028 & 0.0036 & 0.0038 & 0.0034 \\
\hline 0.0038 & 0.0035 & 0.0037 & 0.0035 & 0.0038 & 0.0035 & 0.0045 & 0.0038 & 0.0042 \\
\hline 0.0038 & 0.0035 & 0.003 & 0.0035 & 0.0038 & 0.0035 & 0.0036 & 0.003 & 0.0034 \\
\hline 0.003 & 0.0028 & 0.0037 & 0.0035 & 0.003 & 0.0028 & 0.0027 & 0.0038 & 0.0025 \\
\hline 0.0038 & 0.0035 & 0.0022 & 0.0035 & 0.0038 & 0.0035 & 0.0045 & 0.0038 & 0.0042 \\
\hline 0.003 & 0.0028 & 0.0037 & 0.0028 & 0.003 & 0.0035 & 0.0036 & 0.003 & 0.0034 \\
\hline 0.003 & 0.0035 & 0.0037 & 0.0028 & 0.003 & 0.0035 & 0.0036 & 0.003 & 0.0042 \\
\hline
\end{tabular}

4. Use Equation (7) to obtain the positive ideal solution and negative ideal solution of each influence factor, as shown in Table 7.

Table 7. The distance of positive ideal solution and negative ideal solution of each factor.

\begin{tabular}{cccccccccc}
\hline & $\mathbf{A}_{\mathbf{1}}$ & $\mathbf{A}_{\mathbf{2}}$ & $\mathbf{A}_{\mathbf{3}}$ & $\mathbf{A}_{\mathbf{4}}$ & $\mathbf{A}_{\mathbf{5}}$ & $\mathbf{A}_{\mathbf{6}}$ & $\mathbf{A}_{\mathbf{7}}$ & $\mathbf{A}_{\mathbf{8}}$ & $\mathbf{A}_{\mathbf{9}}$ \\
\hline$S_{i}^{+}$ & 0.0013 & 0.001 & 0.0017 & 0.001 & 0.0013 & 0.001 & 0.0026 & 0.0013 & 0.0022 \\
\hline$S_{i}^{-}$ & 0.0015 & 0.0016 & 0.0034 & 0.0016 & 0.0015 & 0.0016 & 0.0031 & 0.0015 & 0.0033 \\
\hline
\end{tabular}

5. Use Equation (8) to obtain the approaching degree of each influence factor, as shown in Table 8.

Table 8. The approaching degree of each influence factor.

\begin{tabular}{cccccccccc}
\hline & $\mathbf{A}_{\mathbf{1}}$ & $\mathbf{A}_{\mathbf{2}}$ & $\mathbf{A}_{\mathbf{3}}$ & $\mathbf{A}_{\mathbf{4}}$ & $\mathbf{A}_{\mathbf{5}}$ & $\mathbf{A}_{\mathbf{6}}$ & $\mathbf{A}_{\mathbf{7}}$ & $\mathbf{A}_{\mathbf{8}}$ & $\mathbf{A}_{\mathbf{9}}$ \\
\hline$C_{j}$ & 0.5359 & 0.6126 & 0.6721 & 0.6126 & 0.5359 & 0.6126 & 0.5505 & 0.5359 & 0.5941 \\
\hline
\end{tabular}

Data analysis, which was based on the modified Delphi method and nine constructs, revealed the sorting of nine affecting factors. They were, in order of weight, channel (5.00), target customers (4.71), customer relationship (4.71), key activities (4.71), value proposition (4.58), key resources (4.57), cost structure (4.57), revenue model (4.29), and key partners (4.14).

Next, analysis results of the data generated from the modified Delphi method were subjected to Grey-TOPSIS computing for factor weight relationships. The weights of the nine factors, in order of weight, were channel (0.67), target customers (0.61), customer relationship (61), key activities (0.61), revenue model (59), key partners (0.55), value proposition (0.54), key resources (0.54), and cost structure (0.54). 
The work investigated hotel sub-branding in terms of a business model. Nine affecting factors were identified, among which channel, target customers, customer relationship, and key activities were regarded as the most important. Marketing channel used to be considered as an important link between purchase and sale. The overall process of channeling is supposed to shorten the distance between production and sale. Consumer evaluation for a hotel can be affected by web service image (Kim et al. 2017; Ghahtarani et al. 2020; Tiago et al. 2021). Therefore, a traveling website and platform and a hotel booking system and platform management are also very important. The research results of the paper, therefore, are consistent with that of past study.

Targeting customer base also plays an important role in hotel sub-branding. Obviously, employing market segmentation and goal marketing can reduce resource waste. Providing customers who have different values with different channels, marketing methods, and contents can attract customers from individual segments. They are all important factors influencing sub-branding. By customer relationship, we mean a relation model established between an organization and its specific customer base. Past studies pointed out that customer identification with service can help win customer favoritism and increase customer repeat purchases (Tsen and Hu 2010; Ghahtarani et al. 2020). According to the present research, customer relationship is an important factor of hotel sub-branding. The finding, therefore, is consistent with past notions. Whenever an operational model is necessitated, there needs to be a key activity. According to the paper, key activities also play an important part in hotel sub-branding.

\section{Conclusions}

With the change of times, enterprises can use innovation to grasp the market. An innovative business model is very important for the hotel industry to expand its advantages. Opening sub-brands in Taiwan's hotel industry is a new topic now, encouraging the hotel industry to have a new outlook and business model. With this innovative business model, the hotel industry can decide influential factors and decision-making processes while establishing sub-brands.

Based on the nine factors of the business model, the work investigated the strategies of hotel sub-branding. They are channel, target customers, customer relationship, key activities, revenue model, key partners, value proposition, key resources, and cost structure. The top four are the most important ones.

However, it is not easy for the hotel industry to develop a new business model. Hence, this study proposed a new set of business models integrating Multiple Attribute Decision Making (MADM) to evaluate weight analysis and ranking of factors affecting sub-branding development. This finding, figured out by using soft mathematical methods, can provide a proper evaluating way for decision making by the hotel industry, which wants to establish its sub-brands and to reduce the risk of investment and operation management.

According to past research, value proposition was the core determining overall operation activities in sub-branding. In order to satisfy a specific value proposition, we need to have specific customers, channel, key partners, and key activities. The weight sorting of affecting factors, however, does not support such a notion. Therefore, whether there is disparity between consideration priority and the factor importance is worth forthcoming investigation.

Though there are research limitations that this study has, Taiwan, as the scope of the research, and the practices and considerations adopted probably differ from diverse countries. Otherwise, for future research: (1) It is suggested to obtain data from more experts. (2) Further research can apply more soft computing methods, such as grey relational analysis and fuzzy set method, to continue the research. (3) The factors influencing a hotel's sub-branding explored by the paper can be conducted in other hotel groups or other industries, such as hospitality, which plan to set up affiliated restaurants or introduce a new sub-brand. 
Author Contributions: Conceptualization: H.-F.C., S.-H.W. and J.H.-Y.C.; methodology: H.-F.C., S.-H.W. and J.H.-Y.C.; formal analysis: H.-F.C. and J.H.-Y.C.; investigation resources: H.-F.C. and C.-H.K.; writing-original draft preparation, H.-F.C., S.-H.W. and J.H.-Y.C.; writing-review and editing: H.-F.C., S.-H.W. and J.H.-Y.C.; project administration, H.-F.C., S.-H.W. and J.H.-Y.C.; funding acquisition, H.-F.C. and C.-H.K. All authors have read and agreed to the published version of the manuscript.

Funding: The research is grateful to the Ministry of Science and Technology for the funding of the special project MOST 107-2813-C-270-001-H.

Institutional Review Board Statement: Not applicable.

Informed Consent Statement: Not applicable.

Data Availability Statement: Data are available on request to the authors. The data source is obtained from the questionnaire analysis of the authors' research.

Conflicts of Interest: The authors declare no conflict of interest.

\section{References}

Aaker, David A. 1991. Managing Brand Equity: Capitalizing on the Value of a Brand Name. New York: The Free Press.

Agarwal, Sanjeev, M. Krishna Erramilli, and Chekitan S. Dev. 2003. Market orientation and performance in service firms: Role of innovation. The Journal of Services Marketing 17: 68-82. [CrossRef]

Amit, Raphael, and Christoph Zott. 2001. Value Creation in e-business. Strategic Management Journal 22: 493-520. [CrossRef]

Barros, Teresa, Paula Rodrigues, Nelson Duarte, Xue-Feng Shao, Francisco Vitorino Martins, Barandas-Karl Hortênsia, and Xiao-Guang Yue. 2020. The Impact of Brand Relationships on Corporate Brand Identity and Reputation—An Integrative Model. Journal of Risk and Financial Management 13: 133. [CrossRef]

Benner, Mary J., and Michael Tushman. 2002. Process management and technological innovation: A longitudinal study of the photography and paint industries. Administrative Science Quarterly 47: 676-706. [CrossRef]

Cavalcante, Sérgio, Peter Kesting, and John Ulhøi. 2011. Business Model Dynamics and Innovation: (Re)Establishing the Missing Linkages. Management Decision 49: 1327-42. [CrossRef]

Chen, Yen Yao, Nai Fong Kuo, and Hsai Ching Wang. 2015. An Analysis of the Brand Value of the Global Top One Hundred Brands. East Asia Forum Quarterly 490: 23-46.

Chesbrough, Henry. 2010. Business Model Innovation: Opportunities and Barriers. Long Range Planning 43: 354-63. [CrossRef]

Chesbrough, Henry, and Richard S. Rosenbloom. 2002. The role of the business model in capturing value from innovation: Evidence from Xerox Corporation's technology spin-off companies. Industrial E Corporate Change 11: 529-55.

Chien, Grace C. L., and Hsueh-Hua Hung. 2018. The Impact of International Hotel Group Brand Awareness, Brand Image on Customer Satisfaction: Service Quality as a Mediator. Annals of Leisure and Recreation Research 10: 35-69.

Dhiman, Praveen, and Sangeeta Arora. 2020. A conceptual framework for identifying key employee branding dimensions: A study of hospitality industry. Journal of Innovation \& Knowledge 5: 200-9.

Eberhard, Manuel, and Justin Craig. 2013. The evolving role of organisational and personal networks in international market venturing. Journal of World Business 48: 385-97. [CrossRef]

Faherty, Vincent. 1979. Continuing social work education: Results of a Delphi survey. Journal of Education for Social Work 15: 12-19. [CrossRef]

Gambardella, Alfonso, and Anita M. McGahan. 2010. Business-Model Innovation: General Purpose Technologies and their Implications for Industry Structure. Long Range Planning 43: 262-71. [CrossRef]

Geissdoerfer, Martin, Paulo Savaget, and Steve Evans. 2017. The Cambridge business model innovation process. Procedia Manufacturing 8: 262-69. [CrossRef]

Ghahtarani, Alireza, Majid Sheikhmohammady, and Mahdieh Rostami. 2020. The impact of social capital and social interaction on customers' purchase intention, considering knowledge sharing in social commerce context. Journal of Innovation E Knowledge 5: 191-99.

Guarascio, Dario, and Federico Tamagni. 2019. Persistence of innovation and patterns of firm growth. Research Policy 48: 1493-512. [CrossRef]

Holden, Michael C., and John F. Wedman. 1993. Future issues of computer-mediated communication: The results of a delphi study. Educational Technology Research and Development 41: 5-24. [CrossRef]

Holliday, Susan, Prapti Sherchan, and Sarah Ebrahimi. 2020. COVID-19 and the Insurance Industry: Why a Gender-Sensitive Response Matters. Washington, DC: International Finance Corporation.

Huang, Je Sheng, and Wan Hsin Pan. 2012. Reexamining Downward Line Extension Decisions through Brand Concept Maps: Brand Associations as Measurement Indicators. NTU Management Review 23: 85-118.

Hubbard, Raymond, and J. Scott Armstrong. 1994. Replications and Extensions in Marketing: Rarely Published but Quite Contrary. International Journal of Research in Marketing 11: 233-48. [CrossRef] 
Hussain, Ijaz, Shaohong Mu, Muhammad Mohiuddin, Rizwan Qaiser Danish, and Shrafat Ali Sair. 2020. Effects of Sustainable Brand Equity and Marketing Innovation on Market Performance in Hospitality Industry: Mediating Effects of Sustainable Competitive Advantage. Sustainability 12: 2939. [CrossRef]

Jansen, J. P. Justin, Frans A. J. Van Den Bosch, and Henk W. Volberda. 2005. Managing potential and realized absorptive capacity: How do organizational antecedents matter? Academy of Management Journal 48: 999-1015. [CrossRef]

Johne, Axel, and Robert Davies. 2000. Innovation in medium-sized Insurance companies: How marketing adds value. International Journal of Bank Marketing 18: 6-14. [CrossRef]

Kim, Seo Yeon, Jong Uk Kim, and Sang Cheol Park. 2017. The Effects of Perceived Value, Website Trust and Hotel Trust on Online Hotel Booking Intention. Sustainability 9: 2262. [CrossRef]

Koh, Tuan Hoon. 2012. WOW! Multi-Branding Makes WOWprime Successful. Taipei: Yuanliu.

Kotler, Philip. 1991. Marketing Management: Analysis, Planning, Implementation, and Control, 7th ed. Upper Saddle River: Prentice Hall.

Kotler, Philip, Gary Armstrong, John Saunders, and Veronica Wong. 1996. Principles of Marketing: The European Edition. London: Prentice-Hall.

Kuo, Fu Yu. 2015. A Study on the Relationship among Principals' Curriculum Leadership, Teachers' Professional Learning Communities and Teachers' Teaching Efficacy in Vocational High Schools. Ph.D. dissertation, Department of Industrial Education and Technology, National Changhua University of Education, Changhua, Taiwan.

Light, Larry, and Joan Kiddon. 2009. Six Rules for Brand Revitalization: Learn How Companies Like McDonald's Can Re-Energize Their Brands. Upper Saddle River: Pearson Education, Inc.

Lüdeke-Freund, Florian, Stefan Schaltegger, and Krzysztof Dembek. 2019. Strategies and drivrs of sustainable business model innovation. In Handbook of Sustainable Innovation. Edited by Frank Boons and Andrew McMeekin. Cheltenham: Edward Elgar Publishing, pp. 101-23.

Magretta, Joan. 2002. Why Business Models Matter. Harvard Business Review 80: 86-93.

Murry, John W., Jr., and James O. Hammons. 1995. Delphi: A Versatile Methodology for conducting qualitative Research. The Review of Higher Education 18: 423-36. [CrossRef]

Osterwalder, Alexander, and Yves Pigneur. 2010. Business Model Generation: A Handbook for Visionaries, Game Changers, and Challengers. New York: John Wiley \& Sons.

Salguero, Gisela Casado, Manuel Angel Fernández Gámez, Ignacio Aldeanueva Fernández, and Daniel Ruíz Palomo. 2019. Competitive Intelligence and Sustainable Competitive Advantage in the Hotel Industry. Sustainability 11: 1597. [CrossRef]

Sharmelly, Rifat, and Anton Klarin. 2021. Customer Value Creation for the Emerging Market Middle Class: Perspectives from Case Studies in India. Journal of Risk and Financial Management 14: 455. [CrossRef]

Smith, Daniel C. 1992. Brand Extensions and Advertising Efficiency: What can and cannot be Expected. Journal of Advertising Research 32: 11-20.

Taques, Fernando Henrique, Manuel G. López, Leonardo F. Basso, and Nelson Areal. 2020. Indicators used to measure service innovation and manufacturing innovation. Journal of Innovation and Knowledge 6: 11-26. [CrossRef]

Tauber, Edward M. 1981. Brand franchise extension: New product benefits from existing brand names. Business Horizons $24: 36-41$. [CrossRef]

Teece, David J. 2010. Business Model, Business Strategy and Innovation. Long Range Planning 43: 172-94. [CrossRef]

Tiago, Flavio, Artur Gil, Sara Stemberger, and Teresa Borges-Tiago. 2021. Digital sustainability communication in tourism. Journal of Innovation \& Knowledge 6: 27-34.

Tidd, Joe, John Bessant, and Keith Pavitt Chichester. 1997. Managing Innovation: Integrating Technological, Market and Organizational Change. New York: John Wiley \& Sons.

Timmers, Paul. 1998. Business Models for Electronic Markets. Journal on Electronic Markets 8: 3-8. [CrossRef]

Tsen, Shu hsiao, and Hsiang ling Hu. 2010. A Research on the Organizational Competitiveness and the Indicators of the Intellectual Capital: In the case on the International Tourist Hotels. Journal of Human Resource Management 10: 79-104.

Wen, Kun Li, and Hue Chu Wen. 2021. Grey System Theory and Application of Soft Computing. Changhua: Taiwan Kansei Information Association.

Yoon, K. Paul, and Ching Lai Hwang. 1995. Multiple Attribute Decision Making: An Introduction. Thousand Oaks: Sage Publications Inc.

Zahra, Shaker A. 1996. Technology strategy and financial performance: Examining the moderating role of the firm's competitive environment. Journal of Business Venturing 11: 189-219. [CrossRef]

Zhang, Wenyao, Tugrul Daim, and Qingpu Zhang. 2018. Understanding the disruptive business model innovation of e-business microcredit: A comparative case study in China. Technology Analysis and Strategic Management 30: 765-77. [CrossRef] 